\title{
Enteral self-expandable metal stent placement for malignant afferent limb syndrome using single-balloon enteroscope: report of five cases $\square$
}

\section{(ㄷ)(i) $\odot$}

\author{
Authors \\ Kei Yane, Akio Katanuma, Tsuyoshi Hayashi, Kuniyuki Takahashi, Toshifumi Kin, Kazumasa Nagai, Kazunari Tanaka, \\ Naohiro Komatsu, Masato Endo, Yousuke Kobayashi, Yukiko Takigawa, Ran Utsunomiya \\ Institution \\ Center for Gastroenterology, Teine-Keijinkai Hospital, \\ Sapporo, Japan \\ submitted 7.4 .2018 \\ accepted after revision 24.7.2018 \\ Bibliography \\ DOI https://doi.org/10.1055/a-0739-7640 | \\ Endoscopy International Open 2018; 06: E1330-E1335 \\ (c) Georg Thieme Verlag KG Stuttgart · New York \\ ISSN 2364-3722 \\ Corresponding author \\ Kei Yane, MD, Center for Gastroenterology, Teine-Keijinkai \\ Hospital, 1-40 Maeda 1-jo 12-chome, Teine-ku, Sapporo \\ 006-8555, Japan \\ Fax: +81-11-6852967 \\ k.yane3@gmail.com

\section{ABSTRACT} \\ Endoscopic enteral self-expandable metal stent (SEMS) \\ placement is a useful alternative treatment option for ma- \\ lignant afferent limb syndrome (ALS). We investigated the \\ safety, efficacy, and follow-up results of enteral SEMS place- \\ ment using a single-balloon enteroscope for the treatment \\ of malignant ALS.
}

\section{Introduction}

Afferent limb syndrome (ALS), which shows chronic obstruction of the afferent limb from various causes, is a postoperative complication following gastrointestinal surgery [1,2]. Afferent limb obstruction can be caused by afferent limb kinking and angulation, internal herniation, postoperative adhesions, or tumor recurrence. ALS may cause increased epigastric pain, cholestasis, cholangitis, or pancreatitis. Previously, surgical treatment was the definitive therapy for ALS [1]. However, in patients with malignant ALS due to recurrent cancer, less invasive nonsurgical treatment is desirable considering the poor medical condition of the patients.

Recently, advances in endoscopic devices and techniques have led to various management options [2,3]. Among them, treatment using a balloon enteroscope is also promising in complicated reconstructive intestinal tract cases. However, there are apparently only a few case reports of the treatment of malignant ALS by enteral self-expandable metal stent (SEMS) placement using a balloon enteroscope [4 - 9], and little is known about the efficacy, safety, and follow-up results. We report on enteral SEMS placement for malignant ALS using a single-balloon enteroscope (SBE) in five consecutive patients and review previous case reports.

\section{Case series}

Between January 2010 and October 2017, we performed therapeutic endoscopic intervention in five consecutive patients with malignant ALS using SBE. Informed consent to undergo the procedure was obtained from each patient. We examined the procedural details and clinical courses of the patients retrospectively using their medical records and endoscopic database. This study was approved by our institutional review board.

Endoscopic procedures were performed using two types of SBE depending on the period: standard SBE (SIF-Q260; Olympus, Tokyo, Japan) and short SBE (SIF-H290S; Olympus) with an overtube. A standard SBE has a $200 \mathrm{~cm}$ working length and a $2.8 \mathrm{~mm}$ working channel. A short SBE has a $152 \mathrm{~cm}$ working length and a $3.2 \mathrm{~mm}$ working channel. The larger working channel of a short SBE has the advantage of allowing the use of up to 9-Fr devices.

In all patients, the SBE was inserted into the afferent limb using a standard insertion technique. After reaching the stricture site, enterography was performed and the stricture length was confirmed. Then, a guidewire (0.025 inch VisiGlide2; Olympus, or 0.035 inch Jagwire; Boston Scientific, Tokyo, Japan) was inserted across the stricture. In cases wherein it was difficult to 

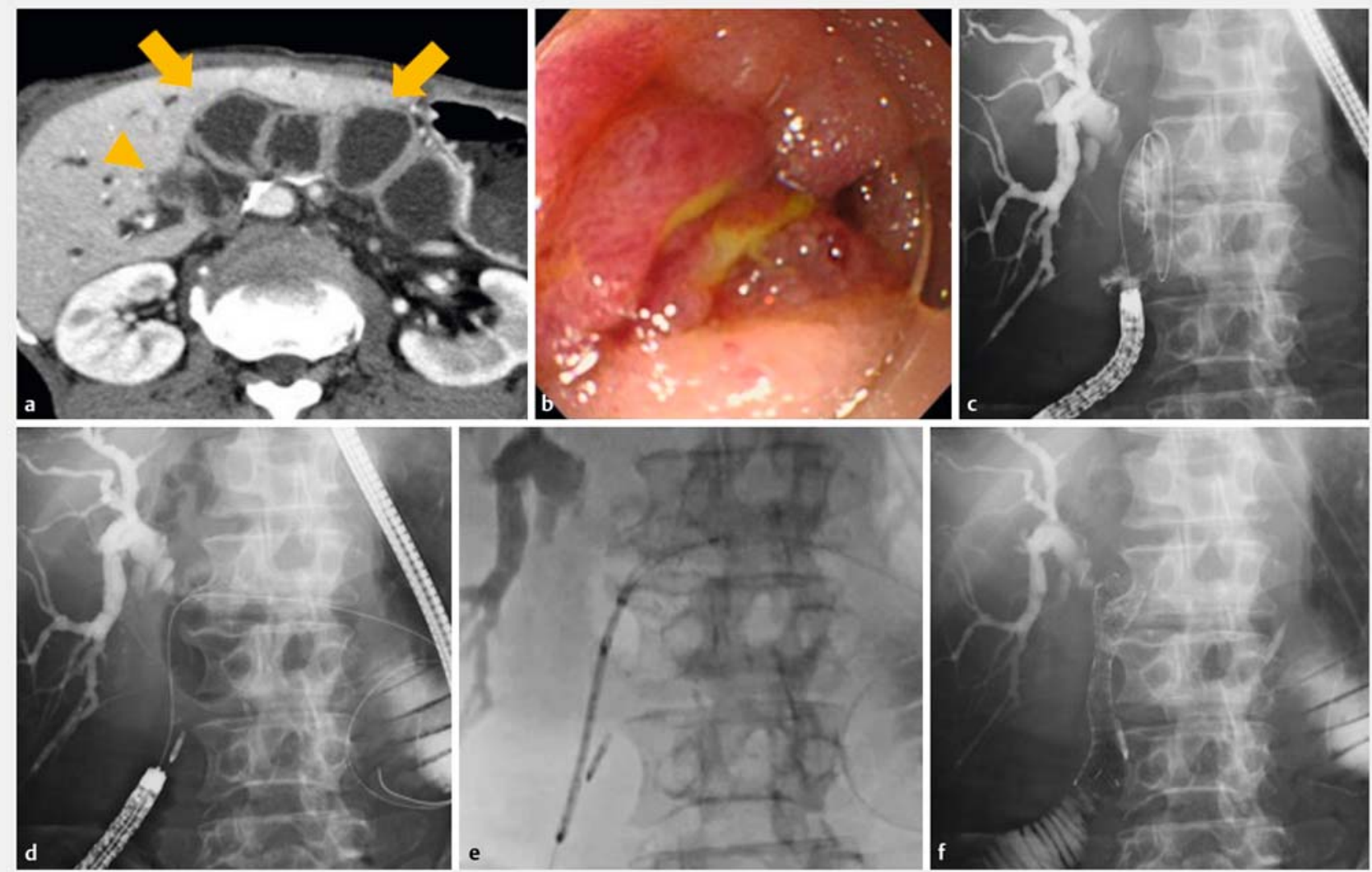

- Fig. 1 Overtube-assisted SEMS placement. a Computed tomography (CT) showing marked dilation of the afferent limb (arrows) and the recurrent tumor (arrowhead). $\mathbf{b}$ Endoscopic image of the stenotic site. $\mathbf{c}$ Enterography showing the afferent limb stenosis. The length of the stenosis was about $3 \mathrm{~cm}$. d A marking clip was placed as a landmark for the stenotic site. e, $\mathbf{f}$ The enteral SEMS was deployed via the overtube.

recognize the accurate stricture site or length, clip placement was performed as a landmark. Following guidewire placement, we performed two types of procedure depending on the situation: the overtube-assisted (OA) method or the through-thescope (TTS) method. In the OA method, after the guidewire had been placed deeply in the afferent limb across the stricture, the enteroscope was removed, leaving the overtube fixed by the balloon and the guidewire in place. Subsequently, an enteral SEMS (22 mm diameter, 60 - 120 mm long, Niti-S pyloric/duodenal D-type stent; Taewoong Medical, Seoul, South Korea, or $22 \mathrm{~mm}$ diameter, 60-120 mm long, WallFlex Duodenal stent; Boston Scientific) delivery system was advanced along the guidewire through the remaining overtube. Thereafter, stent deployment was performed under fluoroscopic guidance ( $\triangleright$ Fig. 1, $\triangleright$ Video 1). After the development of a newly designed enteral stent using a 9-Fr delivery system (18 mm diameter, 60-120 mm long, Niti-S pyloric/Duodenal D-type stent; Taewoong Medical or $22 \mathrm{~mm}$ diameter, 60 - $120 \mathrm{~mm}$ long, Wallflex Duodenal Soft stent; Boston Scientific), we selected the TTS method using a short SBE. In the TTS method, after the guidewire had been placed deeply across the stricture, an enteral SEMS was deployed using direct endoscopic vision under fluoroscopic guidance ( $\triangleright$ Fig. 2, $\triangleright$ Video 2).

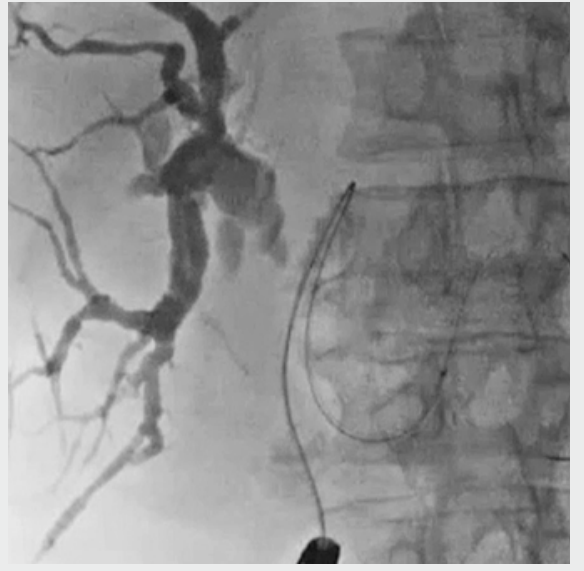

$\checkmark$ Video 1 Overtube-assisted SEMS placement. After the guidewire had been placed across the stricture, the enteroscope was removed, leaving the overtube and the guidewire in place. Subsequently, SEMS deployment was performed under fluoroscopic guidance. 

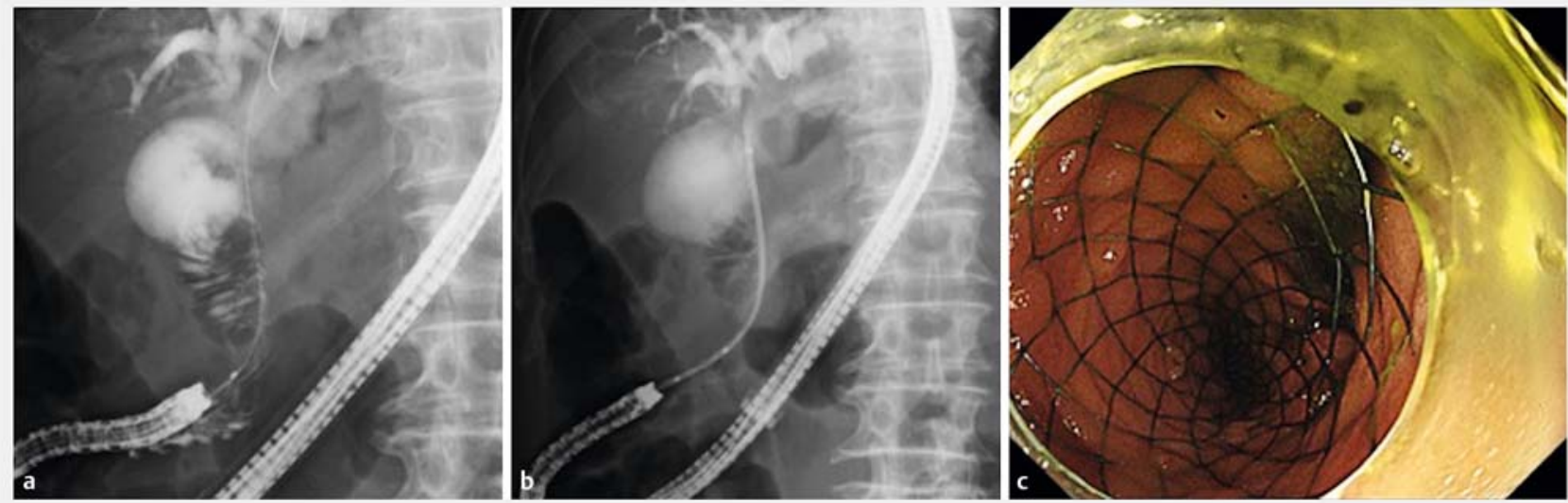

Fig. 2 Through-the-scope SEMS placement: a Fluoroscopic imaging showing malignant afferent limb obstruction. b The stent delivery system was introduced through the scope channel. c SEMS was deployed under direct endoscopic view with fluoroscopic guidance.

The main outcome measures were technical success and clinical success. Technical success was defined as successful intended SEMS placement in the stricture site using an SBE. Clinical success was defined as resolution of clinical symptoms and decreased dilation of the afferent loop from the imaging findings. Adverse events (AEs) were evaluated according to the severity grading system in the American Society for Gastrointestinal Endoscopy's lexicon.

After stent placement, each patient underwent physical examination daily and blood test once a week until discharge. After discharge, each patient underwent physical examination and blood test monthly in an outpatient clinic. The patients were advised to visit the hospital if symptoms developed and they underwent further examination including an imaging diagnostic test. If follow-up could not be carried out at our institute, a telephone interview was conducted.

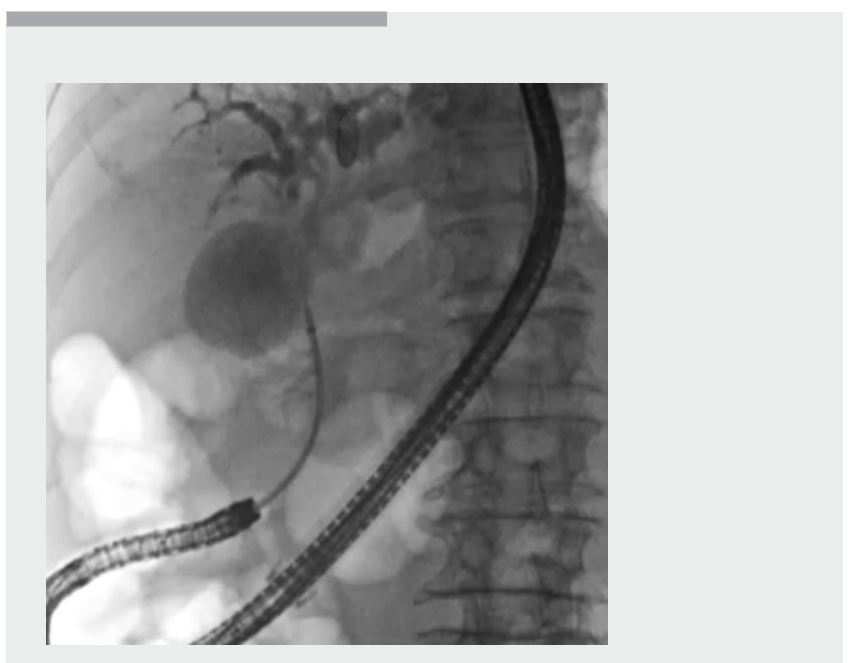

$\checkmark$ Video 2 Through-the-scope SEMS placement. After the guidewire had been placed across the stricture, SEMS deployment was performed using direct endoscopic vision under fluoroscopic guidance.
The clinical characteristics of the patients are summarized in - Table 1. The primary diseases included pancreatic cancer $(n=$ 4 ) and cholangiocarcinoma $(n=1)$. The surgical methods for primary disease treatment included subtotal stomach preserving pancreaticoduodenectomy in four patients (one received prior total gastrectomy) and right hepatectomy with extrahepatic bile duct resection in one patient. The median duration from surgery to endoscopic treatment was 21 months (range, 5-43 months). All five patients had cholangitis, and their computed tomography (CT) images showed afferent bowel loop dilatation due to recurrent tumor. The technical success rate of the endoscopic treatment was $100 \%$ in this case series. The median scope insertion and total procedural times were 33 minutes ( 6 - 48 minutes) and 63 minutes (29-80 minutes), respectively. In four patients, SEMS was deployed using the OA method. In the remaining case, SEMS was deployed using the TTS method. In all patients, the proper position and expansion of the SEMS were confirmed on the following day by abdominal radiography, and there were no post-procedural AEs. Clinical success was achieved in all five patients postoperatively. Four patients died 219, 109, 103, and 84 days after the procedure without recurrent cholangitis. The remaining patient had recurrent cholangitis 114 days after the procedure, and CT showed bile duct dilation without afferent limb obstruction. SBE-assisted endoscopic retrograde cholangiography through the previously placed enteral SEMS revealed a choledochojejunal anastomosis stricture, and balloon dilation of the anastomosis was performed. After the treatment, recurrent cholangitis was not observed during the 651 days until the patient's death. The details of the endoscopic treatment procedure and the outcomes for each patient are summarized in $>$ Table 2. 
- Table 1 Characteristics of patients in our case series.

\begin{tabular}{|c|c|c|c|c|c|c|}
\hline Patient & $\begin{array}{l}\text { Age (years), } \\
\text { sex }\end{array}$ & Primary disease & Reconstruction method & $\begin{array}{l}\text { Duration after sur- } \\
\text { gery (months) }\end{array}$ & Indication & Cause of ALS \\
\hline 1 & $76 \mathrm{M}$ & Pancreatic cancer & $\begin{array}{l}\text { SSPPD (earlier total gas- } \\
\text { trectomy with Roux-en Y } \\
\text { reconstruction) }\end{array}$ & 42 & Cholangitis & Recurrent tumor \\
\hline 2 & $65 \mathrm{M}$ & Pancreatic cancer & SSPPD & 5 & Cholangitis & Recurrent tumor \\
\hline 3 & $59 \mathrm{~F}$ & Pancreatic cancer & SSPPD & 21 & Cholangitis & Recurrent tumor \\
\hline 4 & $77 \mathrm{M}$ & Pancreatic cancer & SSPPD & 7 & Cholangitis & Recurrent tumor \\
\hline 5 & $64 \mathrm{M}$ & Cholangiocarcinoma & $\begin{array}{l}\text { Right hepatectomy with } \\
\text { bile duct resection }\end{array}$ & 43 & Cholangitis & Recurrent tumor \\
\hline
\end{tabular}

ALS, afferent limb syndrome; SSPPD, subtotal stomach preserving pancreaticoduodenectomy.

- Table 2 Details of endoscopic treatment in our case series.

\begin{tabular}{|c|c|c|c|c|c|c|c|c|c|}
\hline \multirow{2}{*}{$\begin{array}{l}\text { Pa- } \\
\text { tient }\end{array}$} & \multirow[t]{2}{*}{ Scope } & \multirow{2}{*}{$\begin{array}{l}\text { Stent de- } \\
\text { ployment } \\
\text { method }\end{array}$} & \multicolumn{3}{|l|}{ Stent } & \multirow{2}{*}{$\begin{array}{l}\text { Proce- } \\
\text { dure } \\
\text { time } \\
\text { (min) }\end{array}$} & \multirow{2}{*}{$\begin{array}{l}\text { Adverse } \\
\text { events }\end{array}$} & \multirow{2}{*}{$\begin{array}{l}\text { Follow- } \\
\text { up } \\
\text { period } \\
\text { (days) }\end{array}$} & \multirow{2}{*}{$\begin{array}{l}\text { Recurrent } \\
\text { cholangitis }\end{array}$} \\
\hline & & & $\begin{array}{l}\text { Delivery } \\
\text { system } \\
\text { size (Fr) }\end{array}$ & $\begin{array}{l}\text { Diameter } \\
(\mathrm{mm})\end{array}$ & $\begin{array}{l}\text { Length } \\
\text { (mm) }\end{array}$ & & & & \\
\hline 1 & Short SBE & $\begin{array}{l}\text { Overtube } \\
\text { assisted }\end{array}$ & 10 & 22 & 120 & 80 & None & 219 & No \\
\hline 2 & Short SBE & $\begin{array}{l}\text { Overtube } \\
\text { assisted }\end{array}$ & 10 & 22 & 80 & 68 & None & 103 & No \\
\hline 3 & Short SBE & $\begin{array}{l}\text { Overtube } \\
\text { assisted }\end{array}$ & 10 & 22 & 100 & 29 & None & 109 & No \\
\hline 4 & Short SBE & $\begin{array}{l}\text { Through- } \\
\text { the-scope }\end{array}$ & 9 & 22 & 60 & 56 & None & 84 & No \\
\hline 5 & Standard SBE & $\begin{array}{l}\text { Overtube } \\
\text { assisted }\end{array}$ & 10 & 22 & 60 & 63 & None & 765 & $\begin{array}{l}\text { Yes (choledo- } \\
\text { chojejunal anas- } \\
\text { tomosis stenosis } \\
114 \text { days after } \\
\text { the procedure) }\end{array}$ \\
\hline
\end{tabular}

SBE, single-balloon enteroscope.

\section{Discussion}

We confirmed the efficacy and safety of enteral SEMS placement using SBE in five patients with malignant ALS.ALS is a postoperative complication in various gastrointestinal surgeries $[1,2]$. The incidence of ALS in pancreatic cancer patients after pancreaticoduodenectomy is reported to be $13 \%$ [2]. In addition, one-third of the ALS in this population was caused by recurrent pancreatic cancer.

Although surgery is the standard therapy for ALS, it is highly invasive for patients with noncurative malignant disease, particularly pancreatobiliary cancer. On the other hand, the percutaneous transhepatic approach is a well-established treatment for ALS [10]. However, it usually requires two steps: percutaneous transhepatic biliary drainage (PTBD) and stent placement along the PTBD tract 1 or more weeks later. Therefore, the percutaneous approach is relatively invasive and time-consuming. Although the one-step direct percutaneous enteral stent inser- tion technique has also been reported, it has a high risk of bile leakage. Furthermore, in patients without intrahepatic bile duct dilation, the percutaneous approach is difficult and occasionally not possible. On the other hand, enteroscopy enables patients to undergo one-step enteral metal stent placement which can contribute to the maintenance of a patient's quality of life [2,3]. In addition, enteroscopy can be performed in patients with a bleeding tendency (e.g., severe coagulopathy or receiving anticoagulation therapy) who are at a high risk for surgery and percutaneous treatment. However, in patients with a long and tortuous afferent bowel loop before stenosis, the endoscopic approach is thought to be difficult.

At present, balloon enteroscope-assisted endoscopic intervention includes enteral metal stent placement, which is applied in the treatment of several conditions in patients with surgically altered anatomy. In our PubMed search, there were six reports (eight patients) in which SEMS was placed for the treatment of malignant ALS using a balloon enteroscope ( $>$ Table 3 ) 
- Table 3 Summary of other studies using enteral metal stent placement for malignant afferent limb syndrome with a balloon enteroscope.

\begin{tabular}{|c|c|c|c|c|c|c|c|c|c|c|}
\hline \multirow[t]{2}{*}{ Reference } & \multirow{2}{*}{$\begin{array}{l}\text { Num- } \\
\text { ber } \\
\text { of pa- } \\
\text { tients }\end{array}$} & \multirow{2}{*}{$\begin{array}{l}\text { Primary } \\
\text { disease }\end{array}$} & \multirow{2}{*}{$\begin{array}{l}\text { Recon- } \\
\text { struction } \\
\text { method }\end{array}$} & \multirow[t]{2}{*}{ Scope } & \multirow{2}{*}{$\begin{array}{l}\text { Stent de- } \\
\text { ployment } \\
\text { method }\end{array}$} & \multicolumn{2}{|l|}{ Stent } & \multirow{2}{*}{$\begin{array}{l}\text { Clini- } \\
\text { cal } \\
\text { suc- } \\
\text { cess }\end{array}$} & \multirow{2}{*}{$\begin{array}{l}\text { Adverse } \\
\text { events }\end{array}$} & \multirow[t]{2}{*}{ Outcome } \\
\hline & & & & & & $\begin{array}{l}\text { Diam- } \\
\text { eter } \\
(\mathrm{mm})\end{array}$ & $\begin{array}{l}\text { Length } \\
(\mathrm{mm})\end{array}$ & & & \\
\hline $\begin{array}{l}\text { Kida et al. } \\
2013 \text { [4] }\end{array}$ & 1 & $\begin{array}{l}\text { Pancreatic } \\
\text { cancer }\end{array}$ & PPPD & $\begin{array}{l}\text { Standard } \\
\text { DBE }\end{array}$ & $\begin{array}{l}\text { Overtube } \\
\text { assisted }\end{array}$ & NA & NA & Yes & None & NA \\
\hline $\begin{array}{l}\text { Sasaki et al. } \\
2014 \text { [5] }\end{array}$ & 1 & $\begin{array}{l}\text { Pancreatic } \\
\text { neuroendo- } \\
\text { crine carci- } \\
\text { noma }\end{array}$ & $\begin{array}{l}\text { PD with } \\
\text { R-Y }\end{array}$ & $\begin{array}{l}\text { Standard } \\
\text { DBE }\end{array}$ & $\begin{array}{l}\text { Overtube } \\
\text { assisted }\end{array}$ & 22 & 60 & Yes & None & NA \\
\hline $\begin{array}{l}\text { Nakahara et } \\
\text { al. } 2015 \text { [6] }\end{array}$ & 2 & $\begin{array}{l}\text { Pancreatic } \\
\text { cancer (1), } \\
\text { cholangio- } \\
\text { carcinoma } \\
\text { (1) }\end{array}$ & PPPD (2) & $\begin{array}{l}\text { Standard } \\
\text { SBE }\end{array}$ & $\begin{array}{l}\text { Overtube } \\
\text { assisted }\end{array}$ & 22 & 120 & Yes & $\begin{array}{l}\text { Ascending } \\
\text { cholangi- } \\
\text { tis (1) }\end{array}$ & $\begin{array}{l}\text { No recur- } \\
\text { rent cho- } \\
\text { langitis } \\
\text { (4 months, } \\
14 \text { months) }\end{array}$ \\
\hline $\begin{array}{l}\text { Shimatani et } \\
\text { al. } 2016 \text { [7] }\end{array}$ & 1 & $\begin{array}{l}\text { Pancreatic } \\
\text { cancer }\end{array}$ & PD & Short DBE & $\begin{array}{l}\text { Through- } \\
\text { the-scope }\end{array}$ & 18 & 60 & Yes & None & NA \\
\hline $\begin{array}{l}\text { Minaga et al. } \\
2016 \text { [8] }\end{array}$ & 1 & $\begin{array}{l}\text { Duodenal } \\
\text { cancer }\end{array}$ & PD & Short SBE & $\begin{array}{l}\text { Through- } \\
\text { the-scope }\end{array}$ & 18 & 80 & Yes & None & NA \\
\hline $\begin{array}{l}\text { Kanno et al. } \\
2018 \text { [9] }\end{array}$ & 2 & $\begin{array}{l}\text { Cholangio- } \\
\text { carcinoma } \\
\text { (1), gastric } \\
\text { cancer (1) }\end{array}$ & $\begin{array}{l}\text { PD (1), } \\
\text { TG with } \\
\text { R-Y }\end{array}$ & Short SBE & $\begin{array}{l}\text { Through- } \\
\text { the-scope }\end{array}$ & 18 & 80,100 & Yes & None & $\begin{array}{l}\text { No recur- } \\
\text { rent cho- } \\
\text { langitis } \\
\text { ( } 1 \text { month, } \\
12 \text { months) }\end{array}$ \\
\hline
\end{tabular}

PD, pancreaticoduodenectomy; PPPD, pylorus-preserving pancreaticoduodenectomy; DBE, double-balloon enteroscope; R-Y, Roux-en Y reconstruction; SBE, singleballoon enteroscope; TG, total gastrectomy.

[4-9]. Four patients were treated using the OA method and the remaining four patients using the TTS method. SEMS placement on the target site was successful in all patients; subsequently, clinical success was achieved. Recently, a newly designed balloon enteroscope with a shorter scope length and a larger working channel, and enteral SEMS with a smaller delivery system enabled us to perform TTS SEMS placement under direct endoscopic view with fluoroscopic guidance. This technique appears to be easier, safer, and more accurate than OA SEMS placement [7-9].

To the best of our knowledge, there have been few reports to date about post-procedural outcomes after endoscopic enteral SEMS placement for malignant ALS [6,9]. Our case series showed satisfactory follow-up results without apparent recurrent cholangitis due to obstruction of the enteral SEMS over the remaining life of the patients. Furthermore, it is theoretically possible to perform additional SEMS placement if SEMS occlusion occurs.

Enteral SEMS placement using SBE is an effective, less invasive, promising treatment method for malignant ALS. Further accumulation of cases, examination of safety and efficacy, and evaluation of follow-up results are warranted to confirm our results.

\section{Acknowledgments}

We are indebted to Dr. Edward Barroga (http://orcid.org/00000002-8920-2607) for the editorial review of the manuscript.

\section{Competing interests}

None

References

[1] Eagon JC, Miedema BW, Kelly KA. Postgastrectomy syndromes. Surg Clin North Am 1992; 72: 445-465

[2] Pannala R, Brandabur JJ, Gan SI et al. Afferent limb syndrome and delayed $\mathrm{Gl}$ problems after pancreaticoduodenectomy for pancreatic cancer: single-center, 14-year experience. Gastrointest Endosc 2011; 74: $295-302$

[3] Huang J, Hao S, Yang F et al. Endoscopic metal enteral stent placement for malignant afferent loop syndrome after pancreaticoduodenectomy. Wideochir Inne Tech Maloinwazyjne 2015; 10: 257-265

[4] Kida A, Matsuda K, Noda Y. Endoscopic metallic stenting by doubleballoon enteroscope and its overtube for malignant gastrointestinal obstruction as palliative treatment. Dig Endosc 2013; 25: 552 - 553

[5] Sasaki T, Isayama H, Kogure H et al. Double-balloon enteroscope-assisted enteral stent placement for malignant afferent-loop obstruction after Roux-en-Y reconstruction. Endoscopy 2014; 46: (Suppl. 01): E541-542 
[6] Nakahara K, Okuse C, Matsumoto $\mathrm{N}$ et al. Enteral metallic stenting by balloon enteroscope for obstruction of surgically reconstructed intestine. World J Gastroenterol 2015; 21: 7589-7593

[7] Shimatani M, Takaoka M, Tokuhara M et al. Through-the-scope selfexpanding metal stent placement using newly developed short double-balloon endoscope for the effective management of malignant afferent-loop obstruction. Endoscopy 2016; 48: (Suppl. 01): E6 - 7

[8] Minaga K, Kitano M, Takenaka M. Through-the-scope enteral metal stent placement using a short-type single-balloon enteroscope for malignant surgically reconstructed jejunal stenosis (with video). Dig Endosc 2016; 28: 758

[9] Kanno Y, Ohira T, Harada Y et al. Metal stent placement in the afferent loop obstructed by peritoneal metastases - experience of five cases. Clin Endosc 2018; 51: 299- 303

[10] Han K, Song HY, Kim JH et al. Afferent loop syndrome: treatment by means of the placement of dual stents. AJR Am J Roentgenol 2012; 199: $761-766$ 